\title{
MOVEMENT ACTIVITY DETERMINATION WITH HEALTH-RELATED VARIABLES OF UNIVERSITY STUDENTS IN KOSICE
}

\section{DOLOČANJE GIBALNE DEJAVNOSTI S SPREMENLJIVKAMI NA PODROČJU ZDRAVJA PRI UNIVERZITETNIH ŠTUDENTIH V MESTU KOŠICE}

\author{
Peter BAKALÁR ${ }^{1}$, Martin ZVONAR ${ }^{2 *}$, Jaromir SEDLACEK ${ }^{3}$, Rut LENKOVA ${ }^{3}$, Peter SAGAT ${ }^{4}$, \\ Lubos VOJTASKO ${ }^{5,3}$, Erika LIPTAKOVA ${ }^{6}$, Miroslava BARCALOVA ${ }^{5,7}$
}

'Pavol Jozef Šafárik University, Institute of Physical Education and Sports, Ondavská 21, Kosice, Slovakia

${ }^{2}$ Masaryk University, Faculty od Sports Studies, Kamenice 5, Brno, Czech Republic

${ }^{3}$ University of Presov, Faculty of Sport, Department of Sports Kinanthropology, 17th November Str., Presov, Slovakia

${ }^{4}$ Prince Sultan University Riyadh, Department of Physical Education, Riyadh, Saudy Arabia

${ }^{5}$ Technical University of Kosice, Department of Physical Education, Vysokoškolská 4, Kosice, Slovakia

${ }^{6}$ Technical University of Kosice, Faculty of Economics,

Department of Applied Mathematics and Business Informatics, Němcovej 32, Kosice, Slovakia

${ }^{7}$ Technical University of Kosice, Faculty of Mechanical Engineering,

Department of Biomedical Engineering and Measurement, Letná 9, Kosice, Slovakia

\section{ABSTRACT}

Keywords:

Physical activity, percentage body fat, Body mass index, Waist-hip ratio, university students

\section{IZVLEČEK}

Ključne besede: telesna dejavnost, odstotek telesne maščobe, indeks telesne mase, razmerje med pasom in boki, univerzitetni študenti
Introduction: There is currently a strong scientific evidence about the negative health consequences of physical inactivity. One of the potential tools for promoting physical activity at the institutional level of the Ecological model is to create conditions and settings that would enable pupils, students and employees engage in some form of physical activity. However, physical activities as a subject are being eliminated from the study programs at Slovak universities. The purpose of the study was to find current evidence about the level of structured physical activity and health-related variables in university students in Košice.

Material and methods: The sample consisted of 1,993 or, more precisely, 1,398 students who attended two universities in Košice. To collect data, students completed a questionnaire and were tested for body height, body weight, circumferential measures and percentage body fat.

Results: The university students did not sufficiently engage in a structured physical activity. A large number of students had either low or high values of percentage body fat and BMI and high WHR values.

Conclusions: Our findings have shown that the research into physical activity of university students should receive more attention.

Uvod: Trenutno imamo na voljo zelo trdne znanstvene dokaze o negativnih telesnih posledicah zaradi telesne nedejavnosti. Eno izmed morebitnih orodij za promocijo telesne dejavnosti na institucionalni ravni Ekološkega modela je ustvarjanje pogojev in okolja, ki omogoča učencem, študentom in zaposlenim vključevanje $v$ določeno telesno dejavnost. Na univerzah na Slovaškem se telesne dejavnosti kot predmet izločajo iz študijskih programov. Namen študije je raziskovanje trenutnih dokazov o ravni strukturirane telesne dejavnosti in spremenljivk, ki so povezane z zdravjem pri študentih $v$ mestu Košice.

Gradivo in metode: Vzorec je vključeval 1.993, ali natančneje 1.398 študentov, ki obiskujejo obe univerzi v mestu Košice. Zbiranje podatkov je potekalo v obliki vprašalnika, ki so ga študenti izpolnili, ter testiranja za pridobivanje podatkov o telesni višini, telesni teži, obodnih vrednosti in odstotka telesne maščobe.

Rezultati: Univerzitetni študenti se ne vključujejo $v$ strukturirane telesne dejavnosti $v$ zadostni meri. Visoko število študentov ima prenizke ali previsoke vrednosti za odstotek telesne maščobe in indeks telesne mase ter visoke vrednosti pri razmerju med pasom in boki.

Zaključek: Ugotovitve nakazujejo, da bi morali raziskovanju telesne dejavnosti univerzitetnih študentov posvečati več pozornosti. 


\section{INTRODUCTION}

At present, we have strong scientific evidence on the negative health consequences of lack of movement activity, which we define as 'the behaviour of an individual with a low volume of normal physical activity and the deficit of structured movement activities with the prevalence of sedentary lifestyle' (1). In the Slovak Republic, according to the Eurobarometer 2014 (2), no ordinary physical activity, such as cycling from place to place or gardening, is practiced by $19 \%$ of the population, and up to $41 \%$ of the population does not practice any physical exercise or any sport, which represents an increase of $6 \%$ compared to 2009. Thus, the low level of physical activity can be considered a public policy problem that needs to be addressed at the national level (3). One of the theoretical concepts applicable to the promotion of mobility of the population is the Ecological Model of Behaviour (4). For the above model, the desired change in behaviour, in our case, the increase in the level of movement activity, will be more successful if we focus on influencing as many of the correlates and determinants of motion activity. We will work through multiple interventions at different levels (individual, interpersonal, institutional, communal and public) at the same time (5). At the institutional level, which includes schools, companies, health facilities or civic associations, it is possible to support mobility activities by creating conditions and environments for carrying out a specific physical activity for pupils, students, employees or residents (6). Especially in the case of schools, we have a tool for influencing a large number of individuals in the direction of their physical education. In the academic year 2015/16, despite the long-term decreasing trend in the number of university students, 149,031 citizens of the Slovak Republic (together with foreigners, it is 158,659 students) were studying at Slovak universities (7), accounting for about $2.8 \%$ of the whole Slovak population. University education is, for the majority of them, often the last formal learning environment in which they can acquire the knowledge and skills needed to lead an active lifestyle with lifelong positive health benefits $(8,9)$. Research suggests that incorporating compulsory education related with health or physical activity into university education studies may impact on health-related knowledge, attitudes and real behaviour in graduates (10). At the Slovak universities, however, we can, paradoxically, watch the opposite trend, when physical activities as a subject are often excluded from study programs, even among optional subjects, at humanities faculties, and in teacher study programs (11). From 36 Slovak and 4 foreign universities operating in Slovakia, it provides teaching of physical activity for students of 23 universities (57.5\%) (12).

\subsection{Objectives}

On the example of two of two Slovak universities, Technical University of Kosice (TUKE) and P. J. Safarik University in Kosice (UPJS), we analyse the frequency of structured physical activity and health-related variables of their students, both in the context of the obligation and selection of hours of physical activity during university studies.

\section{MATERIALS AND METHODS}

In our research, are involved 3391 students from two Kosice universities, TUKE and UPJS. Data were collected in the academic year 2012/2013, in two waves, October/ November 2012 and April/ May 2013. There was applied questionnaire and measurements of somatic parameters. During the winter term, in October/ November 2012, 1993 students were involved (sample S1), 810 males and 1183 females; 1042 were students from TUKE and 951 from UPJS. During the summer term, in April/ May 2013, we again collected data from the next 1398 students (sample S2), 558 males and 840 females, 645 from TUKE and 753 from UPJS.

For the needs of this study, we prepared a non-standardized questionnaire, from which we gathered students' age, gender, the year of study, and the frequency of structured exercise activity during the last 6 months.

Somatic parameters were learned by measuring in an indoor sports hall. Students were dressed in light sports closing (shorts and T-shirts). Parameter body height (BH) was measured according to the instructions in sports metrology (13). Apparatus Omron BF 511 was used to learn values of the parameters body weight (BW), Body Mass Index (BMI) and percentage of body fat (\% fat). Waist-hip ratio was measured with measuring tailor tape. according to instructions of the WHO (2011).

When evaluating the percentage of fat, we used the classification of Gallagher et al. (14) listed in the OMRON BF 511 manual for men and women of age 18-39. For men, the values were $<8 \%$ low, $8.0-19.9 \%$ normal, $20.0-24.9$ high and $\geq 25 \%$ very high. For females, the values were $<21 \%$ low, $21.0-32.9 \%$ normal, $33.0-38.9 \%$ high and $\geq 39$ very high.

WHR values were classified according to the WHO recommendations (15), and with respect to gender dimorphism - females: $<0.75$ excellent, $0.75-0.79$ good, $0.80-0.86$ average and $>0.86$ at risk, and males: $<0.85$ excellent, 0.85-0.89 good, 0.90-0.95 average and $>0.95$ at risk. 
BMI was evaluated according to the WHO classification (16): $\leq 18.5$ underweight, between 18.5 and 24.9 normal (healthy) weight, 25.0-29.9 overweight, and $\geq 30$ obese.

To assess the significance of differences between groups in the frequency of structured movement activity, body fat percentage, BMI and WHR, we used the Kruskal Wallis test. We divided the research groups according to the year of study, into three sub-groups, namely: the 1st year, 2nd year, 3rd-6th year. To evaluate the magnitude of the statistical significance of the differences in the mean values of the monitored indicators, we used the t-test for independent files. Statistical significance was evaluated at $\mathrm{p}<0.05$.

Pedagogical interpretation is based on fundamental logical methods, mainly on analysis, comparison and generalization.

\section{RESULTS}

The basic characteristics of S1 and S2 are shown in Table 1. The mean values of the body height of both male and female groups were in the average body height of the Slovak population (13) of this age (average male 173-185 $\mathrm{cm}$ and female intervals $163-172 \mathrm{~cm}$ ). The average body weight of male S1 was at the upper limit of the mean weight and the average weight of the S2 set in the overweight interval (male average $64-77 \mathrm{~kg}$, overweight 77-89 kg). The average body weight of both groups of females was in the range of average population body weight $(52-64 \mathrm{~kg})$.
At the beginning of the academic year 2012/2013, from a total of 18,505 students of TUKE and UPJS, the subject physical activity was chosen by 2958 freshmen, 1622 in the second, 352 in the third, 412 in the fourth, 142 in the fifth and 5 in the sixth year of study. Obligation to complete the subject physical activities for all students of the 1st year and 2nd year of the UPJS Medical Faculty ( $n=406$ resp. 407) and some other faculties of TUKE was reflected in their high percentage of enrolled students of the above years (74.9\% and $46.8 \%$, respectively).

The selectivity of physical activity subject in the 3rd to 6th years of both universities was again reflected in a significant drop in the number of students in physical activity lessons (Figure 1).

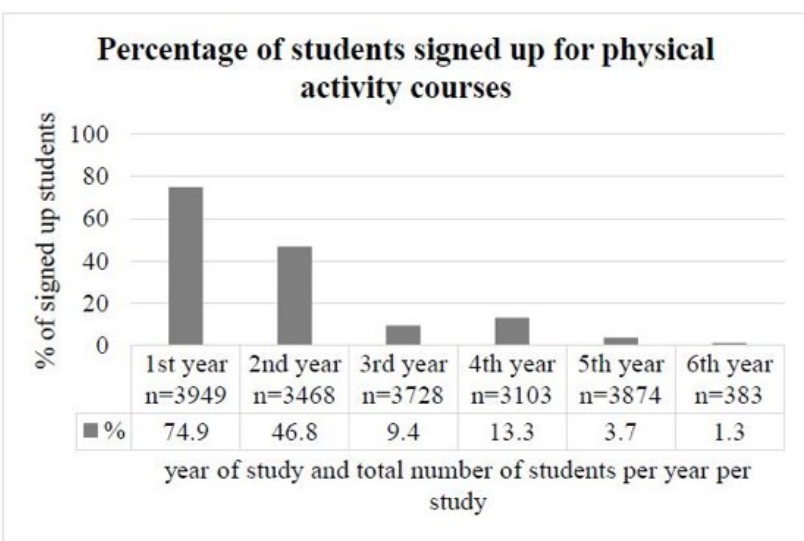

Figure 1. Percentages of TUKE and UPJS students signed for PA courses in each study year.

Table 1. Fundamental characteristics of our groups according to gender and year of study.

\begin{tabular}{|c|c|c|c|c|c|c|c|c|}
\hline \multirow[b]{2}{*}{ Males } & \multicolumn{2}{|c|}{$1^{\text {st }}$ year $(n)$} & \multicolumn{2}{|c|}{$2^{\text {st }}$ year $(n)$} & \multicolumn{2}{|c|}{$3^{\text {rd }}-6^{\text {th }}$ year $(n)$} & \multicolumn{2}{|c|}{ Total (N) } \\
\hline & $\mathrm{S} 1, \mathrm{n}=518$ & $S 2, n=376$ & $\mathrm{~S} 1, \mathrm{n}=204$ & $S 2, n=146$ & $\mathrm{~S} 1, \mathrm{n}=88$ & $S 2, n=36$ & $\mathrm{~S} 1, \mathrm{n}=810$ & $S 2, n=558$ \\
\hline Age & $19.7 \pm 1.7$ & $20.7 \pm 1.3$ & $20.7 \pm 1.2$ & $21.9 \pm 1.3$ & $23.1 \pm 3.8$ & $23.2 \pm 1.4$ & $20.3 \pm 2.2$ & $21.1 \pm 1.5$ \\
\hline $\mathrm{BH}(\mathrm{cm})$ & $179.2 \pm 6.6$ & $180 \pm 6.4$ & $179.0 \pm 6.8$ & $180.3 \pm 6.2$ & $178.5 \pm 7.0$ & $178.7 \pm 7.7$ & $179.1 \pm 6.7$ & $180.0 \pm 6.5$ \\
\hline BW(kg) & $75.7 \pm 12.7$ & $77.9 \pm 13.7$ & $77.6 \pm 14.4$ & $80.4 \pm 11.5$ & $79.3 \pm 18.2$ & $78.5 \pm 13.2$ & $76.6 \pm 13.9$ & $78.6 \pm 13.1$ \\
\hline Females & $n=622$ & $n=448$ & $n=367$ & $n=276$ & $n=194$ & $n=116$ & $N=1183$ & $N=840$ \\
\hline Age & $20.0 \pm 2.6$ & $20.8 \pm 1.9$ & $20.8 \pm 2.8$ & $21.7 \pm 2.2$ & $22.7 \pm 2.8$ & $23.1 \pm 1.4$ & $20.7 \pm 2.8$ & $21.4 \pm 2.1$ \\
\hline $\mathrm{BH}(\mathrm{cm})$ & $166.1 \pm 6.3$ & $166.7 \pm 6.1$ & $166.2 \pm 6.2$ & $167.4 \pm 6.1$ & $166.7 \pm 6.0$ & $167.6 \pm 5.7$ & $166.2 \pm 6.2$ & $167.1 \pm 6.1$ \\
\hline$B W(k g)$ & $60.3 \pm 10.5$ & $59.6 \pm 9.7$ & $60.4 \pm 10.8$ & $61.2 \pm 11.8$ & $59.8 \pm 9.6$ & $59.5 \pm 8.8$ & $60.2 \pm 10.4$ & $60.1 \pm 10.3$ \\
\hline
\end{tabular}

Legend: S1 - sample 1 (September 2012); S2 - sample 2 (May 2013) 
By analysing the frequency of structured movement activity, we found that $38.8 \%$ of males and $62.9 \%$ of $\mathrm{S} 1$ females (beginning of the academic year) were involved in structured movement activity irregularly or not at all. At the same time, among males, the number of students engaged in exercise activity was 3 times a week higher than that of females. The influence of gender on the frequency of structured physical activity of university students was confirmed by our previous studies (17), as well as by another study by Mota and Esculcas (18). In S2 (the end of academic year), $13.6 \%$ of males and $29.7 \%$ of females were irregularly or not attracted to structured physical activity, which is less than in $\mathrm{S} 1$ for males and females. The difference between the two independent groups (S1 and S2) was statistically significant (Table 2). If we consider the performance of structured physical activity 1 times a week as insufficient, we can say that most of our students were not physically active at the beginning of the academic year (52.1\% of males and $76.5 \%$ of females).

Table 2. T-tests between $\mathrm{S} 1$ and $\mathrm{S} 2$ regarding gender and year of study.

\begin{tabular}{|c|c|c|c|c|c|c|c|c|}
\hline \multirow{2}{*}{$\begin{array}{l}\text { Gender: } \\
\text { Health variables: }\end{array}$} & \multicolumn{4}{|c|}{ Males } & \multicolumn{4}{|c|}{ Females } \\
\hline & FSPA & \%FAT & BMI & WHR & FSPA & \%FAT & BMI & WHR \\
\hline \multicolumn{9}{|l|}{$1^{\text {st }}$ year } \\
\hline S1 & $3.3 \pm 1.4$ & $19.1 \pm 7.5$ & $23.6 \pm 3.7$ & $0.84 \pm 0.07$ & $2.6 \pm 1.2$ & $29.9 \pm 7.7$ & $21.8 \pm 3.6$ & $0,77 \pm 0,07$ \\
\hline S2 & $3.8 \pm 1.1$ & $18.8 \pm 7.6$ & $23.9 \pm 3.9$ & $0.85 \pm 0.07$ & $3.3 \pm 1.1$ & $28.7 \pm 6.8$ & $21.3 \pm 3.0$ & $0,74 \pm 0,06$ \\
\hline $\mathrm{p}$ & $0.0001^{*}$ & 0.52 & 0.1498 & $0.0015^{*}$ & $0.0001^{*}$ & $0.0095^{*}$ & $0.0101^{*}$ & $0.0001^{*}$ \\
\hline \multicolumn{9}{|l|}{$2^{\text {nd }}$ year } \\
\hline S1 & $3.4 \pm 1.2$ & $20.4 \pm 7.7$ & $24.2 \pm 4.1$ & $0.84 \pm 0.8$ & $2.8 \pm 1.1$ & $30.5 \pm 7.2$ & $21.9 \pm 3.8$ & $0,76 \pm 0,06$ \\
\hline S2 & $3.9 \pm 1.0$ & $20.5 \pm 7.3$ & $24.6 \pm 3.3$ & $0.86 \pm 0.06$ & $3.3 \pm 1.1$ & $29.2 \pm 7.4$ & $21.8 \pm 3.7$ & $0,74 \pm 0,06$ \\
\hline $\mathrm{p}$ & $0.0004^{*}$ & 0.965 & 0.2591 & $0.0025^{*}$ & $0.0001^{*}$ & $0.024^{*}$ & 0.6519 & $0.0002^{*}$ \\
\hline \multicolumn{9}{|l|}{$3^{\text {rd }}-6^{\text {th }}$ year } \\
\hline S1 & $3.3 \pm 1.3$ & $21.4 \pm 8.0$ & $24.5 \pm 4.1$ & $0.86 \pm 0.09$ & $2.8 \pm 1.1$ & $29.8 \pm 6.8$ & $21.5 \pm 3.1$ & $0,76 \pm 0,06$ \\
\hline S2 & $3.8 \pm 1.1$ & $20.4 \pm 7.0$ & $24.4 \pm 3.1$ & $0.85 \pm 0.07$ & $3.4 \pm 1.1$ & $28.7 \pm 6.6$ & $21.3 \pm 3.2$ & $0,73 \pm 0,08$ \\
\hline$p$ & $0.0259^{*}$ & 0.5234 & 0.9322 & 0.3231 & $0.0001^{*}$ & 0.1803 & 0.6172 & $0.0122^{*}$ \\
\hline \multicolumn{9}{|l|}{ Total } \\
\hline S1 & $3.4 \pm 1.3$ & $19.7 \pm 7.6$ & $23.8 \pm 3.9$ & $0.84 \pm 0.08$ & $2.7 \pm 1.1$ & $30.1 \pm 7.4$ & $21.8 \pm 3.6$ & $0,76 \pm 0,07$ \\
\hline S2 & $3.8 \pm 1.1$ & $19.3 \pm 7.5$ & $24.2 \pm 3.8$ & $0.86 \pm 0.07$ & $3.3 \pm 1.1$ & $28.9 \pm 7.0$ & $21.4 \pm 3.3$ & $0,74 \pm 0,06$ \\
\hline $\mathrm{p}$ & $0.0001^{*}$ & 0.3877 & 0.11 & $0.0004^{*}$ & $0.0001^{*}$ & $0.0003^{*}$ & $0.0271^{*}$ & $0.0001^{*}$ \\
\hline
\end{tabular}

Legend: S1 - sample 1 (September 2012); S2 - sample 2 (May 2013); FSPA - frequency of structured physical activity (1); \%FAT - body fat percentage (\%); BMI - body mass index (kg. m-2); WHR - waist hip rate (1); ${ }^{*}<0.05$. 
In both groups of males and females (S1 and S2), we found higher average values of body fat (norms according to Gallagher et al., 2000 are $8-19.9 \%$ for men and 21$32.9 \%$ for women). More authors prove that there exist some systematic differences depending on the way of gaining data (19). Our apparatus OMRON BF 511 slightly overvalues the percentage of body fat, compared to skin folders (20) or apparatus OMRON BF $306(21,24)$. Despite the system measurement error, the measured results can be used to compare the percentage of body fat of the groups. For females from S1 group, for example, there were measured higher percentages of body fat, compared to S2 females in all groups in average by $1.2 \%$, with statistically significant differences. Among males, the differences between the groups are not statistically significant. However, there is the trend in increasing the percentage of fat with the higher year of study (Table 3 ), both among males and females.
Average BMI values were found in both men and women of both groups in the recommended bands, with no significant differences between the groups (normal weight men and women 18.50-24.99; WHO, 2014) (Table 4). Several Slovak authors have come to similar results (19-25). In monitoring the distribution of students within single BMI bands, we found that, in case of males, $26.3 \%$ of S1 and $26.7 \%$ of S2 were in the overweight band, and $6 \%$ and $7.3 \%$, respectively, in the obesity band. For our females, this distribution was smaller with $12.1 \%$ of $\mathrm{S} 1$ and $10.5 \%$ of S2 groups in the overweight band, and 3.5\% and $1.9 \%$, respectively, in the obesity band. The incidence of underweight in females was $11.7 \%$ in $\mathrm{S} 1$ and $14.5 \%$ in S2 (Table 4).

Table 3. T-tests between S1 and S2 regarding gender and year of study.

\begin{tabular}{|c|c|c|c|c|c|c|c|c|c|c|c|}
\hline \multicolumn{6}{|c|}{ Males } & \multicolumn{6}{|c|}{ Females } \\
\hline$N$ & Norms & $\begin{array}{c}\text { Low } \\
>25.0<8.0\end{array}$ & $\begin{array}{l}\text { Normal } \\
8.0-19.9\end{array}$ & $\begin{array}{c}\text { High } \\
20.0-24.9\end{array}$ & $\begin{array}{c}\text { Very high } \\
>25.0\end{array}$ & $\mathbf{N}$ & Norms & $\begin{array}{l}\text { Low } \\
<20.9\end{array}$ & $\begin{array}{c}\text { Normal } \\
21.0-32.9\end{array}$ & $\begin{array}{c}\text { High } \\
33.0-38.9\end{array}$ & $\begin{array}{c}\text { Very high } \\
>39.0\end{array}$ \\
\hline S1 & $\mathrm{n}$ & 26 & 430 & 175 & 179 & $\mathrm{~S} 1$ & $\mathrm{n}$ & 103 & 714 & 225 & 141 \\
\hline 810 & $\%$ & 3.2 & 53.1 & 21.6 & 22.1 & 1183 & $\%$ & 8.7 & 60.4 & 19 & 11.9 \\
\hline S2 & $\mathrm{n}$ & 27 & 297 & 117 & 117 & S2 & $\mathrm{n}$ & 100 & 519 & 160 & 61 \\
\hline 558 & $\%$ & 4.8 & 53.2 & 21 & 21 & 840 & $\%$ & 11.9 & 60.9 & 19 & 7.3 \\
\hline
\end{tabular}

Legend: S1 - sample 1 (September 2012); S2 - sample 2 (May 2013).

Table 4. Absolute and relative distribution of BMI in September 2012 and May 2013 measurements.

\begin{tabular}{|c|c|c|c|c|c|c|c|c|c|c|c|}
\hline \multicolumn{6}{|c|}{ Males, BMI } & \multicolumn{6}{|c|}{ Females, BMI } \\
\hline$N$ & Norms & $<18.5$ & $18.5-24.9$ & $25-29.9$ & $30.0>$ & $\mathbf{N}$ & Norms & $<18.5$ & $18.5-24.9$ & $25-29.9$ & $30.0>$ \\
\hline S1 & $\mathrm{n}$ & 28 & 520 & 213 & 49 & S1 & $\mathrm{n}$ & 139 & 860 & 143 & 41 \\
\hline 810 & $\%$ & 3.5 & 64.2 & 26.3 & 6 & 1183 & $\%$ & 11.7 & 72.7 & 12.1 & 3.5 \\
\hline S2 & $\mathrm{n}$ & 11 & 357 & 149 & 41 & S2 & $\mathrm{n}$ & 122 & 614 & 88 & 16 \\
\hline 558 & $\%$ & 2.0 & 64 & 26.7 & 7.3 & 840 & $\%$ & 14.5 & 73.1 & 10.5 & 1.9 \\
\hline
\end{tabular}

Legend: S1 - sample 1 (September 2012); S2 - sample 2 (May 2013). 
Average values of WHR of our group, both males and females, were found (Table 2 ) in recommended bands (norms of males $\leq 0.95$ and females $\leq 0,85$; WHO, 2011). Risk values of WHR can be seen among males of $\mathrm{S} 1$ in $5.4 \%$, and of $\mathrm{S} 2$ in $6.5 \%$. For females in $\mathrm{S} 1$, it was $7.8 \%$, and for $52,3.9 \%$ (Table 5). For these men and women, we can talk about increased health risks. In the first and second year of study groups, we observed a WHR index increase trend among males, but females, on the contrary, had a decrease in WHR in both groups. These trends were also manifested in a significant difference between both men and women. Similar results were also found by other authors (22-26).

Table 5. Absolute and relative distribution of WHR in September 2012 and May 2013 measurements.

\begin{tabular}{|c|c|c|c|c|c|c|c|c|c|c|c|}
\hline \multicolumn{6}{|c|}{ Males } & \multicolumn{6}{|c|}{ Females } \\
\hline$N$ & Norms & $\begin{array}{c}\text { Excellent } \\
\quad<0.85\end{array}$ & $\begin{array}{c}\text { Good } \\
0.85-0.89\end{array}$ & $\begin{array}{c}\text { Average } \\
0.90-0.95\end{array}$ & $\begin{array}{l}\text { At risk } \\
0.96>\end{array}$ & $\mathbf{N}$ & Norms & $\begin{array}{c}\text { Excellent } \\
<0.75\end{array}$ & $\begin{array}{c}\text { Good } \\
0.75-0.79\end{array}$ & $\begin{array}{c}\text { Average } \\
0.80-0.85\end{array}$ & $\begin{array}{c}\text { At risk } \\
0.86>\end{array}$ \\
\hline $\mathrm{S} 1$ & $\mathrm{n}$ & 470 & 203 & 93 & 44 & S1 & $\mathrm{n}$ & 534 & 348 & 209 & 92 \\
\hline 810 & $\%$ & 58 & 25.1 & 11.5 & 5.4 & 1183 & $\%$ & 45.1 & 29.4 & 17.7 & 7.8 \\
\hline S2 & $\mathrm{n}$ & 262 & 160 & 100 & 36 & S2 & $\mathrm{n}$ & 535 & 198 & 74 & 33 \\
\hline 558 & $\%$ & 47 & 28.7 & 17.9 & 6.5 & 840 & $\%$ & 63.7 & 23.6 & 8.8 & 3.9 \\
\hline
\end{tabular}

Legend: S1 - sample 1 (September 2012); S2 - sample 2 (May 2013).

\section{DISCUSSION}

A significant decrease in the number of students present at physical activity lessons in the higher years of study (although we do not have complete facts about their physical activity), is for us a strong indicator of a lower interest in structured physical activity in higher years of university studies. Both groups of males and females that we observed at the beginning of school year (S1), were significantly less physically active, like groups at the end of school year (S2). From this, we can deduce that the compulsory subject of physical activity could lead to one of its main goals - to increase the level of physical activity of university students. Another deduction can be about the negative influence of summer vacations on the volume of movement activity. These findings relate mainly to the 1st and 2nd year of study, in which the comparison of differences in the frequency of structured movement activity was statistically significant in both men and women. The question is why students from the $3 \mathrm{rd}$ to the 6th year of schooling disappear from the hours of optional movement activities. Should not the obligation to pass a physical activity lead the students to take free hours of physical activity to maintain a higher level of their physical fitness? Did not we teach them that during the lessons? Should hours of physical activity be compulsory throughout the whole study? Or should we choose a different format (10), the introduction of compulsory hours of the subject Health Education, including not only physical education (practical and theoretical part), but also health psychology and nutrition education that can lead to long-term positive results. According to Keating et al. (28), there are three main reasons as to why we are unable to increase the level of physical activity of university students through their participation in lessons of physical activity, namely:

- Research on the physical activity of university students is not sufficient;

- research of the physical activity of university students lacks a multilevel approach (individual, interpersonal, institutional, communal and public);

- movement activity diagnostic tools are subjective and inconsistent, making comparisons of movement activity parameters between individual groups difficult or impossible.

Of course, thinking that changing all university students to practice regularly physical activities would be naive. However, not to attempt to influence as many of them as possible would be irresponsible from point of view of society in the light of the negative health, economic and social consequences of physical activity deficiency. 
As stated in the University Act itself in Slovakia (29), the mission of higher education institutions is to develop a harmonious personality, knowledge, wisdom, good and creativity in man and to contribute to the development of education, science, culture and health for the welfare of society as a whole, thereby contributing to develop a knowledge-based society ... e.g. via contributing to the prevention and treatment of diseases. Considering both normal and structured physical activities as equivalent in terms of their health benefits (1), we think that the place of structured physical activity in movement education is indispensable. At the same time, numerous groups of individuals with low or high percentages of body fat and BMI as well as high WHR values should be our primary target groups in the field of health education for university students.

\section{CONCLUSIONS AND RECOMMEDATIONS}

The frequency of structured movement activity of students of selected colleges of high education is inadequate. Its support in the form of lessons of movement activities has its social justification in its current form, as well as its hidden limitations and deficiencies, the identification of which should be the subject of further research into the physical activity of university students. Considering the need to apply the multilevel approach, based on our findings on the prevalence of risk values with healthassociated variables and considering the methodological weaknesses of our study, we therefore recommend further research in the following fields:

1. Monitoring of individual parameters of physical activity of university students (frequency, intensity, type and time of movement activities) at all universities in the Slovak Republic with a uniform diagnostic tool (subjective or objective). Our study is an example of the use of a non-standardized subjective diagnostic tool, in which we focus only on monitoring the frequency of structured movement activity, without identifying intensity, kind and time involved in a physical activity.

2. Monitoring health-related variables (the percentage of body fat, BMI, WHR) at all universities in the Slovak Republic by a uniform methodical procedure.

3. Monitoring the correlations of physical activity of college students in the research of identified groups of correlates of physical activity: a) demographic and biological factors, b) psychological, cognitive and emotional factors, c) attributes of behaviour and skills, d) social and cultural factors, e) environmental factors and $f$ ) characteristics of movement activity (30-32).
4. Monitoring the determinants of physical activity of university students through the monitoring of the influence of obligatory passing of hours of movement activities in the subject of Health Education, as independent variables, together with healthrelated indicators, knowledge, attitudes and actual behaviour of graduates. This monitoring can take the form of interventions supporting the physical activity of students in well-designed and conducted research experiments.

5. Identification of successful interventions to support physical activity of graduates and their transitions into conditions of other universities.

6. Analysing the structure and evaluation of the quality of the educational process on the lessons of physical activities carried out in the various educational environments of university education institutions. The real situation that only $9.4 \%$ of thirds, $13.3 \%$ of fours, $3.7 \%$ of fifth and $1.3 \%$ of sixths (Figure 1 ) chose physical activity may be, to a certain extent, also a reflection of dissatisfaction with the educational process and the educational environment in which this process takes place. As with other types of sports and fitness equipment in the developing fitness industry in Kosice, the introduction of basic principles of sport management into the management of movement education at universities appears to be a necessary step.

\section{CONFLICTS OF INTEREST}

The authors declare that no conflicts of interest exist.

\section{FUNDING}

The study was supported by the grant project VEGA $1 / 1343 / 12$, entitled 'Selected risk factors of obesity and exercise prevention.'

\section{ETHICAL APPROVAL}

The study has been performed in accordance with the declaration of Helsinki and approved by the Ethical committee of the Faculty of Sports Studies, Masaryk University, Brno, Czech Republic. 


\section{REFERENCES}

1. Dobry L, Cechovska I. Zdravotní benefity pohybové aktivnosti a behaviorální intervence. In: Hendl J, Dobrý L, et al. Zdravotní benefity pohybových aktivit: monitorování, intervence, evaluace. Praha: Karolinum, 2011:14-60.

2. Eurobarometer. Sport and physical activity, 2014. Accessed March 22nd, 2015 at: http://ec.europa.eu/health/nutrition_physical_ activity/docs/ebs_412_en.pdf.

3. Kalman M, Hamrik Z. Je nizka uroven pohybove aktivity verejnepoliticky problem?. Telesna Kultura. 2013;5:96-114.

4. McLeroy KR, Bibeau D, Steckler A, Glanz K. An ecological perspective on health promotion programs. Health Educ Q. 1988;15(4):351-77.

5. Hendl J, Dobry L, et al. Zdravotni benefity pohybovych aktivit: monitorovani, intervence, evaluace Praha: Karolinum, 2011.

6. Bocarro JN, Kanters MA. Leisure, health, and physical activity. In: Dimensions of leisure for life: individuals and society. Champaign: Human Kinetics, 2010:67-87.

7. MSVVS SR: annual reports about state of universities in Slovakia in year 2016. Accessed February 8th, 2017 at: https: / /www.minedu.sk/ vyrocne-spravy-o-stave-vysokeho-skolstva/.

8. McSharry P, Timmins F. An evaluation of the effectiveness of a dedicated health and well-being course on nursing students' health. Nurse Educ Today. 2016;44:26-32. doi: 10.1016/j.nedt.2016.05.004.

9. Sparling PB. College physical education: an unrecognized agent of change in combating inactivity-related diseases. Perspect Biol Med. 2003;46(4):579-87.

10. Pearman SN, Valois RF, Sargent RG, Saunders RP, Drane JW, Macera CA. The impact of a required college health and physical education course on the health status of alumni. J Am Coll Health. 1997;46(2):77-85. doi: 10.1080/07448489709595591.

11. Gerhatova B. Sucasny stav univerzitneho sportu $v$ Slovenskej republike, Ministerstvo skolstva SR. CD-2009-26896/21007. 2009; 5:10.

12. Jancokova L, Pugschova B, Bendikova E. Telesná výchova na vysokých školách v slovenskej republike. ACC J. 2015;21:148-59.

13. Sedlacek J, Cihova I. Športová metrológia. Bratislava: ICM Agency, 2009.

14. Gallagher D, Heymsfield SB, Heo M, Jebb SA, Murgatroyd PR, Sakamoto $Y$. Healthy percentage body fat ranges: an approach for developing guidelines based on body mass index. Am J Clin Nutr. 2000;72(3):694-701.

15. World Health Organisation. Waist circumference and waist-hip ratio: report of a WHO expert consultation, 2011. Accessed February 20th, 2017 at: http://www.who.int/nutrition/publications/obsity/WHO_ report_waistcircumference_and_waisthip_ratio/en/.

16. World Health Organisation. The international classification of adult underweight, overweight and obesity according to BMI, 2014. Accessed January 15th, 2017 at: http://apps.who.int/bmi/index. jsp?introPage=intro_3.html.

17. Bakalar P, Matus I, Hancova M. The comparison of selected lifestyle variables of first-year students at two universities in Kosice. Phys Activ Rev. 2016;4:192-9.
18. Mota J, Esculas C. Leisure-time physical activity behavior: structured and unstructured choices according to sex, age, and level of physical activity. Int J Behav Med. 2002; 9(2):111-21.

19. Brtková $M$, et al. Body composition of undergraduates - comparison of four different measurement methods. Phys Activ Rev. 2014;2:3844.

20. Jurkovicova J, et al. Prevalencia a trendy vyvoja rizikovych faktorov kardiovaskularnych chorob u vysokoskolakov: zivotne podmienky a zdravie. Bratislava: Urad Verejneho Zdravotnictva SR, 2010:142-51.

21. Hrcka J, Kovarova M, Benacka J. Pohybova aktivita edukantov fyzioterapie vo volnom case a jej reflexia na vybranych zdatnostnych a zdravotnych charakteristikach. Trnava: Univerzita sv. Cyrila a Metoda v Trnave, 2011.

22. Hrcka J, Bobrík M, Krska P. Od sebapoznania k autokultivácii cez pohybovú aktivitu vysokoškoláka. Telesná výchova a šport, Bratislava. 2006;16(2):22-6.

23. Krska P. La relation entre le développement physique des filles à l'école primaire et le niveau de leur performance motrice. Rev Int Sci Hum Naturelles. 2011;1:87-94.

24. Petrasova $M$, et al. Obvod pasa alebo BMI?. In: Zivotné podmienky a zdravie. Bratislava: Úrad Verejného Zdravotníctva SR, 2010:166-71.

25. Hertelyova Z, Salaj R, Chmelarova A, Dombrovsky P, Dvorakova MC, Kruzliak P. The association between lipid parameters and obesity in university students. J Endocrinol Invest. 2016;39(7):769-78. doi: 10.1007/s40618-015-0240-8.

26. Zidek J. Longitudinálne hodnotenie stavu telesného rozvoja študentov SJF STU Bratislava. In: 17. rocnik Medzinárodnej vedeckej konferencie »Od vyskumu k praxi«, 29.-30.11.2012. Bratislava: Nakladatel'stvo STU, 2012:379-83.

27. Honz O, Cepkova A. Hodnotenie stavu telesneho rozvoja studentov povinnej telesnej vychovy. In: Telesna vychova, sport, vyskum na univerzitach. Zbornik referatov z 15 . rocnika medzinarodnej vedeckej konferencie, 25.-26.11.2010. Bratislava: STU Bratislava, 2010:47-51.

28. Keating XD Guan J, Piñero JC, Bridges DM. A meta-analysis of college students' physical activity behaviors. J Am Coll Health. 2005;54(2):116-25. doi: 10.3200/JACH.54.2.116-126.

29. Zákon o vysokých školách 2014. Accessed February 1st, 2017 at: http://jaspi.justice.gov.sk/jaspiw1/htm_zak/jaspiw_zak_print.asp.

30. Trost SG Owen N, Bauman AE, Sallis JF, Brown W. Correlates of adults' participation in physical activity: review and update. Med Sci Sports Exerc. 2002;34(12):1996-2001. doi: 10.1249/01. MSS.0000038974.76900.92.

31. Sallis JF, Prochaska JJ, Taylor WC. A review of correlates of physical activity of children and adolescents. Med Sci Sports Exerc. 2000;32(5):963-75.

32. Cerar K, Kondrič $M$, Sindik J. The profiling of University of Ljubljana students according to their motives for exercise participation. Zdr Varst. 2017;56:107-14. doi: 10.1515/sjph-2017-0014. 